\title{
準無矛盾論理に基づく議論フレームワーク
}

\section{An Argumentation Framework based on Paraconsistent Logic}

\author{
梅田 勇一 \\ 新潟大学大学院自然科学研究科 \\ Graduate School of Science and Technology, Niigata University \\ umeda@cs.ie.niigata-u.ac.jp, http://www.cs.ie.niigata-u.ac.jp/ umeda/ \\ 高橋 武久 \\ (同上) \\ takehisa@cs.ie.niigata-u.ac.jp, http://www.cs.ie.niigata-u.ac.jp/ takehisa/ \\ 沢村 一
Hajime Sawamura

\section{新潟大学工学部情報工学科} \\ Department of Information Engineering, Faculty of Engineering, Niigata University \\ sawamura@cs.ie.niigata-u.ac.jp, http://www.cs.ie.niigata-u.ac.jp/ sawamura/
}

keywords: paraconsistent logic programming, argument, argumentation framework, agent

\section{Summary}

Argumentation is the most representative of intelligent activities of humans. Therefore, it is natural to think that it could have many implications for artificial intelligence and computer science as well. Specifically, argumentation may be considered a most primitive capability for interaction among computational agents.

In this paper we present an argumentation framework based on the four-valued paraconsistent logic. Tolerance and acceptance of inconsistency that this logic has as its logical feature allow for arguments on inconsistent knowledge bases with which we are often confronted. We introduce various concepts for argumentation, such as arguments, attack relations, argument justification, preferential criteria of arguments based on social norms, and so on, in a way proper to the four-valued paraconsistent logic. Then, we provide the fixpoint semantics and dialectical proof theory for our argumentation framework. We also give the proofs of the soundness and completeness.

\section{1. は じめ に}

日常社会において , 人々は問題解決の際に議論を行う ことが多い，乥の目的は一般に多樣であるが，たとえば 対立の解消, 相手の説得, 候補の吟味・選択, 交渉, 調 停，情報探索などがある．

一方マルチェージェントの世界においては，エージェ ントか㳔話や交渉を通して衝突を回避し,協調行動をとっ て問題解決を行うことが期待されている [Ferber 99] .こ のような衝突回避や合意形成を実現するための手段のひ とつとして, 計算機科学において議論が注目されてきて いる [Carlos 00] .

実際，計算機科学上の議論モデルはこれまでに多数提 案されてきている . 代表的な議論モデルとしては，互い に反論を投げ合って論争を行い構文的な優先判断基準の もとで勝ち負けを決める Loui のモデル [Loui 87] , 弱 い否定を導入した知識表現のもとで優劣関係を用いて議 論間の比較・攻撃を行う Prakken らのモデル [Prakken 97]などがある．また，情報システムに議論を適用した 例として，弁証法的推論を考慮した合意形成と知識の補 強による協調の実現を特徵とした筆者らのエージェント システム [Umeda 00, 梅田 02], 効用理論と過去の事例
に基づく推論を組み合わせて意思決定を行う Sycara の PERSUADER[Sycara 90]，クライアントの顧客情報を 持つェージェントと見積り案を作成するェージェントが 議論によって対話を行いながら最適な見積りを作成する Schroeder の ADEPT [Schroeder 99]などがある .

これらの研究は知識表現言語として主に拡張論理プロ グラムを用いている．しかし，拡張論理プログラムでは 知識の矛盾を許す意味論が存在するものの，弚れに基づ いて議論を行うための枠組みはいまだ提案されていない． ところが , 現実に行われる議論の中では, 参加者の主張や 議論の結論が矛盾した認識となる場合がある，乥こで我々 は, エージェントが議論を行うための議論フレームワー クに準無矛盾論理を導入することを試みる。準無矛盾論 理は，矛盾した命題から任意の命題が導かれることが起 こらないことを第一の目的として考えられた論理であり， 矛盾した状態を矛盾のまま扱っても問題がない．この論 理の導入により，矛盾した認識の主張を積極的に扱う議 論フレームワークが実現できる.このようなアプローチ で議論フレームワークを豊かにするという試みは筆者の 知る限り，他の文献では見当たらない .

以下 2 章では, 論文全体の構造を明らかにするため， 議論を行うェージェントの概要について述べる .3 章で 
は, 議論を行うための知識表現を準無矛盾論理に基づき 定義する . 4 章では, 知識ベースからの議論の作成と議 論同士の攻撃関係について定義し, 議論フレームワーク を提案する .5 章では, 妥当な議論を一意に決めるため の意味論を与える . 6 章では, 議論が妥当であるか否か を対話的に決定するための証明論を与える .

\section{2. 論争するエージェント}

本論文は, 準無矛盾論理のもとで複数のエージェント が互いに主張を出し合い, 光の中から正しい結論を決め るための議論フレームワークを構筑することを目的とす る .一般にはこのような，互いに意見を交わし論じ合う 行為を議論と呼ぶことが多いが, 本論文ではこの行為を 論争と呼ぶ .この章ではエージェントが行う論争の概観 を与えるため, 論争するエージェントの概要と, エージェ ントか論争を行う背景について述べる。

\section{$2 \cdot 1$ 論争するエージェント の概要}

ここでは, 本論文で提案する議論フレームワークのも とで論争を行うェージェントの性質と, エージェントが 行う論争の流机について述べる.

・各エージェントは固有の知識ベースを持つ .

・エージェントの知識ベースを準無矛盾論理で表現す る (3 章参照) .これによって新たに表現可能となる 問題の例を $3 \cdot 4$ 節で示す

・各エージェントは, 特定の命題を証明する推論の列 を自分の知識べースから構築する .これを本論文で は議論と呼び ( 4 章参照)，論争と区別して扱う。

・エージェント全体の集合をエージェント社会とする．

・エージェント社会内で，ある命題 (議題) に対して どの認識がより正当であるかを決める必要がある場 合，エージェント社会に属するエージェントたちは 6 章の対話的証明論のもとで論争を行う .この背景 について, $2 \cdot 2$ 節で補足する。

・論争では，まずあるエージェントか議題に関する議 論を作成し，提出する。他のエージェントは，提出 された議論に対して乥れを攻撃できる議論が作成て きれば，反論として提出する (議論間の攻撃関係に ついては $4 \cdot 2$ 節で定義する) .このようにして，直 前に提出された議論に反論することを繰り返し，ど の議論に対しても反論が乥れ以上提出できない場合， 論争は終了する.

・論争終了後，最初に提出された議論に対する反論の 状態を調べることにより，最初の議論が正当と認め られるか否かを判定する．どのような議論が正当と いえるのかについては 5 章で定義する

・以上の過程を通して，エージェントたちは互いに議 論・反論を出し合いながら，正しい認識を選ぶこと ができる．これによって，対立した状況の解消・合
意形成・意思決定などが実現できる ${ }^{* 1}$.

3 章以降では, エージェントが以上のような流れで論 争を行うための知識表現，議論の意味論，対話的証明論 を順に定義することにより，議論フレームワークの構築 を行う.

\section{$2 \cdot 2$ エージェント 社会と論争}

エージェント社会は複数のエージェントで構成されて おり，各エージェントの知識ベースは关れ光れ異なる．乥 のため, 社会の中で意思の統一を图ったり行動の方向性 を決めようとしたりする際，各エージェントの間て認識が 食い違うという問題が発生する.このような場合にエー ジェントは論争を行う.論争の中で各エージェントは議論 を作成し提出することによって，主張したい命題が自分 の知識ベースから論理的帰結として出てくることを他の エージェントに示すことができる．また他のエージェン 卜は，提出された議論が自分の知識ベースの内容と相容 れないものであるときに反論を作成し，自らの知識べー スからは異なる論理的帰結が出てくることを示すことが できる.論争ではこのような過程を通して，提出された 議論がェージェント社会全体にとって受け入れられるも のであるかどうかを判定することができる .

この目的から，社会にとって受け入れられる議論を決 めるための基準が必要になる.我々はエージェント社会に 「社会通念」が存在するものと仮定し，社会通念に沿った 議論は高く，社会通念に反した議論は低く評価されると いう比較基準を与える .この社会的な基準と，議論の形 式に基づく基準の 2 種類を用いて議論の比較を行う $(4 \cdot 3$ 節参照) . 社会通念には, 光の社会に属すエージェント の大多数が賛同 (承認) している事柄，例えば社会的な 常識や道德，規範などの内容が含まれるものとする．本 論文では, 社会通念の内容は最初から固定されているも のとし, 光の内容をどのように決めるのか, どのように 更新していくのかについては別の問題として扱う.

\section{3. 準無矛盾論理と知識表現}

ここでは，準無矛盾論理に基づいた知識表現を定義す る。また，この表現で記述された知識ベースからの論理 的帰結を定義する。

\section{$3 \cdot 1$ 準無矛盾論理に基づく 知識表現}

準無矛盾論理は今までにいくつかの種類が提案されて いるが, 我々は [Belnap 77] で提案され [Blair 89, Kifer 92] で展開された，4 值の真理値から構成される準無矛

\footnotetext{
*1 準無矛盾論理を用いたフレームワークではないが, 筆者らは 拡張論理プログラミングを用いた議論フレームワークにおいて 対立の解消だけでなく，協調問題の解決 [Umeda 00, 梅田 02] 妥協・裹歩を用いた合意形成 [Sawamura 00] が実現可能であ ることを既に示している
} 


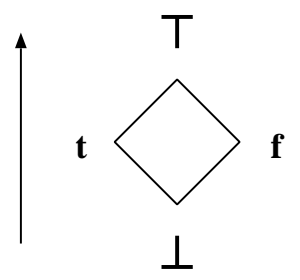

図 1 真理値の順序

盾論理を採用する．この節では弚れらの定義について述 べる。

【定義 1】真理值の集合を $\mathcal{T}=\{\top, \mathbf{t}, \mathbf{f}, \perp\}$ とする .真 理値上の順序を次のように定義する . $(\forall x, y \in \mathcal{T}) x \preceq$ $y \Leftrightarrow x=y \vee x=\perp \vee y=\top$ [Blair 89].

真理値の順序は束構造をとり，図 1 のような Hasse 図 で表すことができる . 真理値は次のような, 命題に対す る認識の違いを表す。

丁: 真でも偽でもある (both) .

$\mathbf{t}:$ 真である (true).

f：偽である (false) .

上: 真でも偽でもない (none) .

リテラルを原子命題または产の否定とする . 真理値で 注釈されたアトム (原始式) とリテラルを以下のように 定義する。

【定義 2】 $A$ をアトム,$L$ をリテラル,$\mu \in \mathcal{T}$ とする. このとき $\mu$ を注釈， $A: \mu$ を注釈つきアトム， $L: \mu$ を注 釈つきリテラルという [Blair 89] ${ }^{* 2}$.

【定義 3】規則は次の形をとる表現である. $L_{0} \Leftarrow L_{1} \wedge$ $\ldots \wedge L_{n}{ }^{* 3}$.ここで, $L_{i}(0 \leq i \leq n)$ は光れ光れ注釈付きリ テラルである [Kifer 92] .

規則の右辺の連言肢 $L_{1}, \cdots, L_{n}$ を, 光の規則の前提と呼 ぶ . また規則の左辺の注釈付きリテラル $L_{0}$ を，乥の規則の 結論と呼ぶ . 前提は空であってもよい. 光のような規則 (事 実節) はとを省略して表記する.エージェントの知識べー スは , この形式の規則の集合である . 以下 , 規則 $r_{1}, \ldots, r_{n}$ から構成される知識ベース $K b$ を $K b=\left\{r_{1}, \ldots, r_{n}\right\}$ ，ま たは $K b=\left\{r_{1}: L_{0}^{1} \Leftarrow L_{1}^{1} \wedge \ldots \wedge L_{m_{1}}^{1}, \cdots, \quad r_{n}: L_{0}^{n} \Leftarrow\right.$ $\left.L_{1}^{n} \wedge \ldots \wedge L_{m_{n}}^{n} \cdot\right\}$ のように表記する .

\section{$3 \cdot 2$ 準無矛盾論理における 論理的帰結}

この節では, [Blair 89, Kifer 92] に従って準無矛盾論 理における知識ベースからの論理的帰結を導入する .

【定義 4】注釈に対する否定を以下のように定義する． $\neg(\mathbf{t})=\mathbf{f}, \neg(\mathbf{f})=\mathbf{t}, \neg(\top)=\top, \neg(\perp)=\perp$ [Blair 89].

【定義 5】 論理式を以下のように定義する [Blair 89]．

・すべての注釈つきリテラルは論理式である .

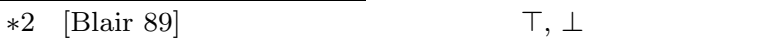
が, [Kifer 92] では光のような拡張が行われている .

*3 変数を含んだ規則は, 光のすべての基礎例 (ground instance) を表しているものとする .
}

- $F_{1}, F_{2}$ か論理式のとき, $F_{1} \wedge F_{2}, F_{1} \Leftarrow F_{2}$ は論理式 である。

【定義 6】 解釈 $I$ をエルブラン基底から真理値への写 像とする．以下のように充足を定義する．ここで，解釈 $I$ が論理式 $F$ を充足することを $I=F$ で表す．また， $I$ が $F$ を充足しないことを $I \not \models F$ で表す [Kifer 92] .

（1） $A: \mu$ を注釈つきアトムとする $I \models A: \mu$ iff $I(A) \succeq \mu$.

（2） $A: \mu$ を注釈つきアトムとする $I \models \neg A: \mu$ iff $I \models A: \neg \mu$.

(3) $F_{1}, \ldots, F_{n}$ を論理式とする $I \models F_{1} \wedge \ldots \wedge F_{n}$ iff すべての $i(i=1, \ldots, n)$ について $I \models F_{i}$.

(4) $F_{1}, F_{2}$ を論理式とする . $I \models F_{1} \Leftarrow F_{2}$ iff $I \models F_{1}$ または $I \not \forall F_{2}$.

【定義 7】モデルを以下のように定義する [Kifer 92] .

- $F$ を論理式とする $I=F$ となるとき, 解釈 $I$ は $F$ のモデルである .

- $K b$ を知識ベースとする.$I$ が $K b$ 内のすべての規則 を充足するとき，解釈 $I$ は $K b$ のモデルである . こ れを $I \models K b$ で表す．

【定義 8】 $K b$ を知識ベース,$I$ を解釈， $F$ を論理式と

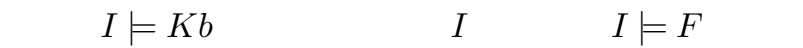
とき, $F$ は $K b$ からの論理的帰結である [Kifer 92] . こ れを $K b=F$ で表す．

〔例 1〕 単独の規則からなる知識ベース $K b_{1}=\{p(a)$ : f. $\}$ を考える.ここで, $I_{1}(p(a))=\top$ となる解釈 $I_{1}$ と，

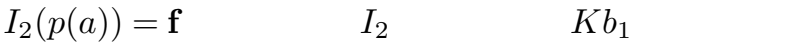
ある $K b_{1}$ のモデルはこれ以外には存在しない .

このとき $, K b_{1} \models p(a): \mathbf{f}$ である $\left(I_{1} \models p(a): \mathbf{f} て ゙ あ り ，\right.$ かつ $I_{2}=p(a): \mathbf{f}$ であるため) . また $, K b_{1} \not \models p(a): \top$ である $\left(I_{2} \not \models p(a): \top\right.$ であるため) .

\section{$3 \cdot 3$ 知識表現の性質}

ここでは, 前節までで定義した知識表現におけるいく つかの性質について述べる．まず，否定された注釈つき リテラルの扱いについて考える .

〈命題 1〉 $K b$ を知識ベースとする $\cdot r^{\prime}$ を，ある規則 $r$ に現れるすべての否定された注釈つきリテラル $\neg L: \mu$ を $L: \neg \mu$ で置き換えた規則とする.$K b^{\prime}$ を $K b$ の各規則 $r_{i}(1 \leq i \leq n)$ を乥れ午れ $r_{i}^{\prime}$ で置き換えた知識べースと する.このとき, 解釈 $I$ が $K b$ のモデルであることと， $I$ が $K b^{\prime}$ のモデルであることは同値である [Blair 89] .

《証明》 定義 $6(2)$ から $I \models r \Leftrightarrow I \models r^{\prime}$. よって自明 .

この結果は, 規則の中の否定された注䣋つきリテラル を否定のない注釈つきリテラルに置き換えても問題がな いことを保証している，乥こで以下の理論展開では，否 定のない注釈つきリテラルのみを考える．

次に，ここまでで定義した知識表現の上では古典論理 における「矛盾する命題の集合からは任意の命題が論理 
的帰結となる」という性質が成り立たないことを次の例 で確認する。

〔例 2〕 次の規則 $r_{1} \sim r_{3}$ からなる知識ベース $K b_{2}$ を 考える.ここで, $X$ は変数を表す $. K b_{2}=\left\{r_{1}: q(X): \mathbf{f}\right.$., $\left.r_{2}: p(a): \mathbf{t} \Leftarrow q(b): \mathbf{f} ., r_{3}: p(a): \mathbf{f}.\right\}$.

この知識ベースにおいて， $r_{1}, r_{2}$ から導き出すことの

できる結論 $p(a): \mathbf{t}$ と $r_{3}$ から導き出すことができる結論 $p(a)$ : $\mathbf{f}$ は古典論理的な意味で矛盾している .しかし，準 無矛盾論理上では $K b_{2}$ から任意の命題か論理的帰結とな ることはない，たとえば， $q(a)$ に t割り当てる解䣋は $K b_{2}$ のモデルになることができず，したがって $q(a): \mathbf{t}$ は $K b_{2}$ の論理的帰結ではない .よって，知識ベースに $p(a): \mathbf{t}$ と $p(a): \mathbf{f}$ の両方が存在するにもかかわらず，任 意の命題か論理的帰結になることはない .

\section{$3 \cdot 4$ 準無矛盾論理の表現能力}

知識表現に 4 值論理を導入することにより，古典論理 上では矛盾となる状態や，真・偽以外の第 3 の真理値を 割り当てるべき状態も扱うことが可能になる．ここでは， 具体的に表現可能となる問題について例を示す．

・是非を一義に決められない問題

例として「死刑制度は是か非か」という問題につ いて考える.多くの人々は，さまざまな理由から「死 刑制度に賛成する」「死刑制度に反対する」のどちら かの意見を支持するのが普通であるが，次のような 意見を持つ人も存在する。

(1) 死刑制度は良いとも悪いとも思う. 弚も光も 合法的に殺人をしてよいのかという点に問題を 感じるが , 被害者遺族の感情が無視できないの も事実である。

（2）賛成・反対のどちらを正しいとするかを判断 するのに十分な判断材料がなく，現状では結論 を出すことができない，

弚れ毞れの意見について，(1) は「賛成 (死刑制 度):丁」という注釈つきリテラルを用いて，(2) は「賛

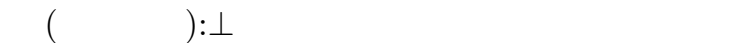
表現することが可能である .

・コミットの表現

上の例であげた死刑制度に関する論争では，「自分 には関わりのない話であり，弚の論争に加わる気は ない」という意見も考えられる．このような「炎の 話題には関心がない, 関わりがない」という考え方 を，真理值 上を用いて表現可能である .

- 損得勘定

物事の損得勘定においては「損をしている」「得を している」という場合以外に，「損もしているし得も している」「損も得もしていない」という状況が日常 的に起こりうる.このような状況を「得をしている (取引):丁.」「得をしている (取引):上.」のような規則 で表現可能である .
・価値判断

絵画や骨董品の価值を判断する際に, 品物の価値 を判断する材料が手元になければ「価值がある」こ とも「価値がない」ことも肯定できないのが普通で

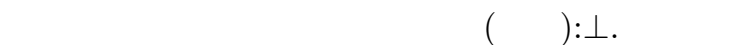
な規則で表現可能である .

\section{4. 議 論}

ここでは 3 章て導入した知識表現のもとで, 準無矛盾論 理に基づく議論フレームワーク $A F=\left\langle K b_{1}, \ldots, K b_{n}, C k\right.$, defeats 〉を構筑する .ここで $K b_{1}, \ldots, K b_{n}$ は知識べース， $C k$ は $4 \cdot 3$ 節で定義する社会通念, defeats は $4 \cdot 3$ 節で定 義する議論間の打破関係を表す

\section{$4 \cdot 1$ 議 論 の 定 義}

【定義 9】 $K b$ を知識べースとする．次の条件を満たす 有限な $K b$ の規則の列 $A=\left[r_{1}, \ldots, r_{n}\right]$ を議論(argument) という．また， $n$ を議論の長さという .

(1) すべての $i(1 \leq i \leq n)$ にいて , 規則 $r_{i}$ の前提で あるすべての注釈付きリテラル $L_{j}: \mu_{j} \quad(1 \leq j \leq m)$ に対し $, L_{j}: \mu_{k}\left(\mu_{k} \succeq \mu_{j}\right)$ を結論とする規則 $r_{k}(k<$ i) が存在する . このとき後者の $L_{j}: \mu_{k}$ を，規則 $r_{i}$ の前提の根拠と呼ぶ .

（2）命題部分が同一となる注釈つきリテラルを結論に 持った複数の規則が含まれない．

定義 9 の条件 (1) は次のことを意味している.議論中 の各規則の前提 $L_{j}: \mu_{j}$ には自分よりも前にある規則の 結論にその根拠 $L_{j}: \mu_{k}$ がなければならない .このとき， 解釈 $I$ が根拠を充足する $\left(I \models L_{j}: \mu_{k}\right)$ ならば， $\mu_{k} \succeq \mu_{j}$ という条件から，I は $L_{j}: \mu_{k}$ を根拠とする前提を充足す る $\left(I \models L_{j}: \mu_{j}\right)$.このことから , 議論の正当性が保証さ れている . 条件 (2) は, 議論内のある規則の結論が $L: \mu$ であるとき，他の規則の結論に $L: \mu$ と $L: \mu^{\prime}\left(\mu \neq \mu^{\prime}\right)$ が含まれないことを意味する．これは，単独の議論内で ひとつの命題に対して複数の主張を持って欲しくないこ とから導入されている (主張の一意性) 。

以下では, $n$ 個の規則 $r_{1}, \ldots, r_{n}$ で構成される議論 $A$ を $A=\left[r_{1}, \ldots, r_{n}\right] ，$ または $A=\left[r_{1}: L_{0}^{1}: \mu_{0}^{1} ., \cdots, r_{n}: L_{0}^{n}:\right.$ $\left.\mu_{0}^{n} \Leftarrow L_{1}^{n}: \mu_{1}^{n} \wedge \ldots \wedge L_{m}^{n}: \mu_{m}^{n}.\right]$ のように表記する . また ， 長さが 0 の議論を空議論と呼ぶ .さらに，部分議論と議 論の結論を次のように定義する

【定義 10】 $A$ を議論とする.$A^{\prime}$ が $A$ の部分列であ り，定義 9 の要件を満たすとき, $A^{\prime}$ を $A$ の部分議論と よぶ。

【定義 11】 $A$ を議論とする $A$ の結論は， $A$ に含ま れるすべての規則の結論の集合である .

議論 $A$ が結論として $L: \mu$ をもつとき， $A$ に含まれる 規則からは $L: \mu^{\prime}\left(\mu \succeq \mu^{\prime}\right)$ も論理的帰結として得られる. しかし， $A$ から得られる論理的帰結の範囲を捉えるには， 
同ーリテラルの中で成り立つ最も高い注釈のみを考慮す ればよいという理由から，本論文では規則の結論である 注釈付きリテラルのみを論理的帰結の代表として議論の 結論とする，という立場をとる.たとえば，例 1 の $K b_{1}$ から得られる論理的帰結は $p(a): \mathbf{f}, p(a): \perp$ であるが， $K b_{1}$ の $r_{1}$ のみから構成される議論の結論は $\{p(a): \mathbf{f}\}$ と なる.この結論は $\ulcorner p(a)$ に対して成り立つ論理的帰結の 範囲は $p(a): \mathbf{f}, p(a): \perp$ である」ということを主張して いる*4.

以上の定義によって知識ベース $K b$ から作成された議 論の結論はすべて,$K b$ のモデルにより充足される.よっ て議論の結論は $K b$ からの論理的帰結であり，議論内の 根拠と結論は論理的帰結関係にある。以下にこれを示す．

〈命題 2〉 知識ベースを $K b$ とする. $K b$ から作成で きる議論の結論は $K b$ からの論理的帰結である .

《証明》 $K b$ から作成できる長さ $i$ の任意の議論を $A_{K b}^{(i)}$ $=\left[r_{1}, \ldots, r_{i}\right]$ とする . また $I$ を $K b$ の任意のモデルとす る . 任意の $i$ につて $A_{K b}^{(i)}$ の結論が $K b$ からの論理的帰 結であることを，議論の長さ $i$ についての数学的帰納法 で示す．

$i=1$ の場合， $A$ は前提のない単一の規則 $r_{1}$ から構成 される議論である.これを $A_{K b}^{(1)}=\left[r_{1}: L: \mu.\right]$ とおく.$I$ は $K b$ 内の規則をすべて充足するから， $r_{1}$ も充足する. $r_{1}$ には前提がないので, 定義 6(4) より $I=L: \mu$.

次に, $A_{K b}^{(n)}$ の結論が $K b$ からの論理的帰結であるとき， $A_{K b}^{(n+1)}$ の結論が $K b$ からの論理的帰結となることを示 す . $A_{K b}^{(n+1)}=\left[r_{1}: L_{0}^{1}: \mu_{0}^{1} ., \cdots, r_{n+1}: L_{0}^{n+1}: \mu_{0}^{n+1} \Leftarrow\right.$ $L_{1}^{n+1}: \mu_{1}^{n+1} \wedge \ldots \wedge L_{m}^{n+1}: \mu_{m}^{n+1}$.] とおく. 帰納法の仮定 より, $I$ は規則 $r_{0} \sim r_{n}$ の結論を充足する $\left(I \models L_{0}^{1}: \mu_{0}^{1}\right.$, $\left.\ldots, L_{0}^{n}: \mu_{0}^{n}\right)$. また定義 9 より， $I \models L_{1}^{n+1}: \mu_{1}^{n+1}, \ldots$, $L_{m}^{n+1}: \mu_{m}^{n+1} . I$ は $K b$ 内の規則をすべて充足するから， $r_{n+1}$ も充足する. 以上のことと定義 $6(4)$ より $I \models L_{0}^{n+1}$ : $\mu_{0}^{n+1}$.

〔 例 3]（議論の例） 以下の規則 $r_{1} \sim r_{5}$ からなる知識 ベースを $K b_{3}$ とする．これは，死刑制度に賛成・反対の 両方の立場を持つ知識ベースの例である .

$K b_{3}=\{$

$r_{1}$ : 癒やす (処刑, 遺族): f.,

$r_{2}$ : 望む (遺族, 死刑): $\mathbf{f} \Leftarrow$ 癒やす (処刑, 遺族): $\mathbf{f}$,

$r_{3}:$ 減少 (犯罪): $\mathbf{t}$.

$r_{4}$ : 抑止 (死刑, 犯罪): $\mathbf{t} \Leftarrow$ 減少 (犯罪): $\mathbf{t}$.

$r_{5}$ : 賛成 (死刑) $: \top \Leftarrow$

望む (遺族, 死刑): $\mathbf{f} \wedge$ 抑止 (死刑, 犯罪): t. $\}$.

$K b_{3}$ から作ることのできる議論として,$A_{1}=\left[r_{1}, r_{2}\right.$, $\left.r_{3}, r_{4}, r_{5}\right]$ がある (図 2 参照) .なぜならば,$r_{2}$ の前提「癒 やす (処刑, 遺族): $\mathbf{f}\lrcorner$ に対して , $r_{1}$ の結論が弚の根拠と なっている．また $r_{4}$ の前提に対する根拠として $r_{3}$ の結 論があり， $r_{5}$ の前提に対する根拠として $r_{2}, r_{4}$ の結論が

$* 4 p(a): \mathbf{f}$ と $p(a): \perp$ を, 独立した結論として光れ光れ主張し ているのではないことに注意

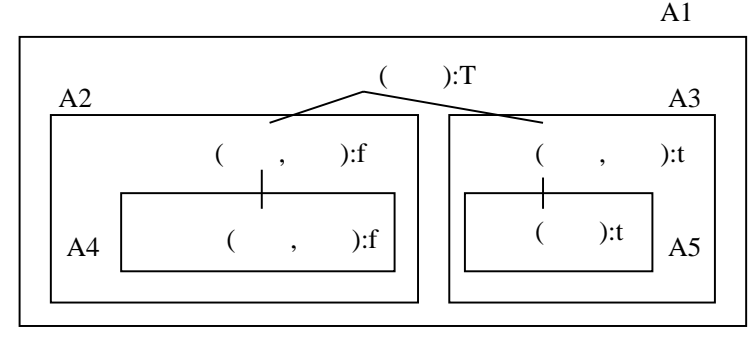

図 2 例 3 の $K b_{3}$ から作られる議論

ある . 同一の命題に関する複数の結論は含まれていない ので, $A_{1}$ は議論である.$K b_{3}$ から作成できる議論として は他に $A_{2}=\left[r_{1}, r_{2}\right], A_{3}=\left[r_{3}, r_{4}\right], A_{4}=\left[r_{1}\right], A_{5}=\left[r_{3}\right]$ があり (図 2 参照)，これらは光れ光れ $A_{1}$ の部分議論 である。

〔 例 4〕 次の 2 つの知識ベース $K b_{4}$ と $K b_{5}$ について考 える. $K b_{4}=\{p(a): \mathbf{t} ., p(a): \mathbf{f}.\} . K b_{5}=\{p(a): \top\}$.

$K b_{4}$ と $K b_{5}$ は光のモデルが一致するので意味的に等 価だと言えるが, $K b_{4}$ から作成できる議論と $K b_{5}$ から 作成できる議論は一致しない，具体的に言えば， $K b_{4}$ か らは $p(a): \mathbf{t}$ と $p(a): \mathbf{f}$ のいずれかを結論に持つ議論を作 成できるが, $p(a): \top$ を結論に持つ議論は作成できない . つまり，知識ベースの書き方の違いによって構成される 議論が異なるということになる．

これはエージェントが知識を個別に持つか，統合され た状態で持つかという違いが兴のまま現れていると考え ることができる．もし $K b_{4}$ を知識ベースに持つエージェ ントが $p(a)$ :丁を結論に持つ議論を作成したければ，光 れを結論に持つ規則を知識ベースに組み入れなければな らない.

\section{$4 \cdot 2$ 議論への攻撃}

この節では, 認識の異なる結論を持つ議論間の攻撃関 係について定義する．

従来の拡張論理プログラミングに基づく議論フレーム ワーク [Carlos 00] では, 議論の結論に対する否定，ある いは仮定に対する否定によって攻撃関係が定義されてい た.しかし 4 值論理上では衝突関係が真理値 $\mathbf{t}, \mathbf{f}$ 間の関 係にとどまらないので, 4 つの真理值の間で何を衝突関 係とするかによって攻撃関係の定義は大きく異なってく る. 我々は, 定義 1 で導入した真理値の順序構造と整合 的な攻撃関係を導入する ${ }^{* 5}$.

【定義 12】 $A_{1}$ を，結論に $L: \mu$ を持つ議論とする. $A_{2}$ を，結論に $L: \mu^{\prime}$ を持つ議論とする.$\mu$ と $\mu^{\prime}$ の間に次のい ずれかの関係が成り立つとき， $A_{1}$ は $A_{2}$ に攻撃(attack) する .

*5 攻撃関係を「同一の命題に対して異なる真理値を主張する結 論があるとき，光れをすべて衝突と捉える」という方針で定義 する考え方もあるが, 本論文では定義 12 の攻撃関係を導入す る。 
- $\mu \preceq \mu^{\prime}$ かつ $\mu \neq \mu^{\prime}$.

• $\mu$ と $\mu^{\prime}$ は順序関係にない .

定義 12 の前者の条件は, 同じリテラルに対して自分 よりも高い真理值を主張する結論を攻撃することを意味 している .たとえば，注釈付きリテラル $L: \mathbf{t}$ を結論に持 つ議論は, $L: \top を$ 結論に持つ議論に対して「リテラル $L$ に対して成り立つ真理值として $丁$ は高過ぎる,$\perp$ と までしか成り立たない」という意味で攻撃を行う.逆に， 同じリテラルに対して自分よりも低い真理值を主張する 結論は自分が主張する論理的帰結の範囲に含まれている ので, これに対しては攻撃は行わない(たとえば $L: \mathrm{t}$ を 結論に持つ議論は， $L: \perp$ が成り立たないことは主張し

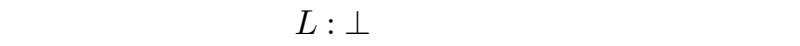
い）.これは，議論の主張はと光の結論から得られる論理 的帰結の範囲で捉えるという考え方 (定義 11 参照) に基 づくものである.一方，定義 12 の後者の条件は 2 值論 理上の攻撃関係，すなわち真理值 $\mathbf{t , ~} \mathbf{f}$ 間の攻撃関係を維 持するためのものである .

議論間に攻撃関係が発生しなければ，対立していると はみなされない，乥こで以下のことを定義する．

【定義 13】議論の集合を Args とする . Args 内の議 論を攻撃する議論が Args に含まれていないとき，Args は無衝突(conflict-free) であるという.

\section{$4 \cdot 3$ 攻撃の比較基準}

定義 12 の攻撃関係には対称的な場合が含まれる. 光 のため，この定義だけでは議論どうしを常に比較できる とは限らない，乥こで, 攻撃を行う議論の優位関係を決 めるための基準を導入する . 判断基準には , エージェン 卜社会の社会通念 $(2 \cdot 2$ 節参照 $)$ から判断する社会的な 基準と，議論の形式的な部分から判断する基準の 2 種類 を準備する．ここで性質の異なった基準を併用するのは， 偏つた視点からの判断を避けるためである．

まず判断基準を定めるための準備として，社会的な基 準の前提となる社会通念を定義する . 社会通念は議論の 結論に関して優位関係を定める目的で導入される . 呂こ で, 社会通念を注釈付きリテラルの集合として定義する ここで, 同一のリテラルに対して複数の社会通念が存在 することは考えない．また日常世界では他の形式 ( 規則 など）の社会通念もありうるが，弚のような拡張性につ いては別の問題として扱う.

【定義 14】社会通念 $C k$ は, 次の条件を満たす注釈 付きリテラルの集合である . $L_{1}: \mu_{1}, L_{2}: \mu_{2} \in C k$ のと き， $L_{1}=L_{2}$ ならば $\mu_{1}=\mu_{2}$.

定義 12 と同樣, 社会通念と同じリテラルに対してより 低い真理値を主張する結論は, 社会通念から見て攻撃対 象に含まれないので社会通念に沿っているとみなす．こ の考えに基づき，社会通念に沿った結論と社会通念に反 する結論を次のように定義する．

【定義 15】 $L: \mu \in C k$ とする $. L: \mu^{\prime}$ を, 議論の結 論である注釈付きリテラルとする.$\mu \succeq \mu^{\prime}$ であるとき， $L: \mu^{\prime}$ は社会通念に沿った結論である .また,$\mu$ と $\mu^{\prime}$ が 順序関係にない，もしくは $\mu \preceq \mu^{\prime}$ かつ $\mu \neq \mu^{\prime}$ のとき， $L: \mu^{\prime}$ は社会通念に反する結論である．

たとえば $L: \mathbf{t} \in C k て ゙ あ る と き, ~ L: \mathbf{t}, L: \perp$ 議論の 結論ならば，社会通念に沿った結論となる . また $L: \mathbf{f}, L$ : 丁か議論の結論ならば，社会通念に反する結論となる． 社会通念に沿った結論どうしか攻撃し合うことは不自 然であるので，次の定義を導入する．

【定義 16】 $A_{1}$ を，結論に $L: \mu_{1}$ を持つ議論とする． $A_{2}$ を，結論に $L: \mu_{2}\left(\mu_{1} \neq \mu_{2}\right)$ を持つ議論とする $. L: \mu_{1}$ と $L: \mu_{2}$ がともに社会通念に沿った結論であるとき， $A_{1}$ は $A_{2}$ に社会的に無効な攻撃をするという.

以上を用いて，次のような判断基準を導入する . 社会 通念に反する結論を持つ議論は , 社会的に受け入れにく いと考えられる．光こで光のような議論を攻撃する場合 は，攻撃する側の議論を優位に扱う．

【定義 17】 $A_{1}, A_{2}$ を議論とする.$A_{1}$ が $A_{2}$ を攻撃し， $A_{2}$ が社会通念に反する結論をもつとき， $A_{1}$ は $A_{2}$ に間 接的に社会的な攻撃をする。

定義 17 の特別な場合として, 社会通念に反する結論 を社会通念と一致した結論で攻撃する場合を区別する．

【定義 18】 $A_{1}$ を，結論に $L: \mu_{1}$ を持つ議論とする． $A_{2}$ を，結論に $L: \mu_{2}\left(\mu_{1} \neq \mu_{2}\right)$ を持つ議論とする $. L:$ $\mu_{1} \in C k$ であり， $L: \mu_{2}$ が社会通念に反する結論である とき， $A_{1}$ は $A_{2}$ に直接的に社会的な攻撃をする.

次に，議論を形式的に比較する基準を導入する．結論 が対立する 2 つの議論について , 対立する結論の根拠の 部分に着目する. 兴れ光れの根拠の部分を比較して包含 関係が成り立つ場合は，より多くの根拠から導かれた結 論を優位に扱う.ただし , 社会的に無効な攻撃に対して はこの比較を行わないものとする .

【定義 19】 $A_{1}$ を, 結論が $L: \mu$ である規則 $r_{1}$ をもつ 議論とする.$A_{2}$ を，結論が $L: \mu^{\prime}$ である規則 $r_{2}$ をもつ 議論とする.$\mu$ と的 について,$\mu \preceq \mu^{\prime}$ かつ $\mu \neq \mu^{\prime}$ であ るか,$\mu$ と $\mu^{\prime}$ は順序関係にないとする . また $, L: \mu$ と $L: \mu^{\prime}$ のうちいずれか一方は社会通念に沿った結論では ないとする . $r_{1}$ の前提の根拠を $S_{1}, r_{2}$ の前提の根拠を $S_{2}$ とする.$S_{2} \subset S_{1}$ が成り立ち，弚の逆が成り立たない とき， $A_{1}$ は $A_{2}$ に根拠の多さに基づく攻撃をする [Loui 87].

定義 17〜19 の 3 つの比較基準について，光れらの間 の強さの順位を次のように定める .

・エージェント社会全体にとって受け入れられる議論 を決めることか論争の目的である $(2 \cdot 2$ 節参照 $)$. 炎 こで, 根拠の多さに基づく攻撃よりも社会的な攻撃 を重視する。

- 社会的な攻撃は直接的な攻撃と間接的な攻撃の $2 つ$ を定義したが, 社会通念と一致した結論で攻撃を行 う前者を優先する。 
この順位を表すため，攻撃のレベルを定義する．

【定義 20】 $A_{1}, A_{2}$ を議論とする . $A_{1}$ の $A_{2}$ に対する 攻撃のレベルを次のように定義する．

- $A_{1}$ が $A_{2}$ に直接的に社会的な攻撃を行うとき，攻撃 のレベルは 4 である .

- $A_{1}$ が $A_{2}$ に間接的に社会的な攻撃を行うとき，攻撃 のレベルは 3 である .

- $A_{1}$ が $A_{2}$ に根拠の多さに基づく攻撃を行うとき，攻 撃のレベルは 2 である .

- $A_{1}$ が $A_{2}$ に攻撃を行うとき, 攻撃のレベルは 1 であ る。ただし， $A_{1}$ が $A_{2}$ に行う攻撃が社会的に無効な 攻撃のみであるとき，攻撃のレベルは 0 である .

- $A_{1}$ が $A_{2}$ に攻撃を行わないとき, 攻撃のレベルは 0 である

$A_{1}, A_{2}$ が上記の複数の条件を満たす場合は, 光の中で 最も高いレベルを適用する .

以上を用いて，打破関係を次のように定義する．

【定義 21】 $A_{1}, A_{2}$ を議論とする． $A_{1}$ が $A_{2}$ を攻撃 し, 弚の攻撃のレベルが $n(n \geq 1)^{* 6}$ であり， $A_{2}$ が $A_{1}$ に 対して乥れを越えるレベルの攻撃ができないとき， $A_{1}$ は $A_{2}$ を打破 (defeat)する.

打破関係は必ずしも対称にはならない，乥こで, 打破 の方向性について以下のことを定義する．

【定義 22】 $A_{1}, A_{2}$ を議論とする． $A_{1}$ が $A_{2}$ を打破 し，弚の逆が成り立たないとき， $A_{1}$ は $A_{2}$ を完全に打 破(strictly defeat)するという.

〔例 5〕 次の知識ベース $K b_{6}, K b_{7}$ を考える .

$K b_{6}=\{$

$r_{1}:$ 減少 (犯罪): t.

$r_{2}:$ 恐れる (犯人, 死): $\top$.,

$r_{3}$ : 抑止 (死刑, 犯罪): $\top \Leftarrow$

減少 (犯罪): $\perp \wedge$ 恐れる (犯人, 死): f. $\}$.

$K b_{7}=\{$

$r_{4}:$ 減少 (犯罪): f.,

$r_{5}$ : 恐れる (犯人, 死): f.,

$r_{6}$ : 抑止 (死刑, 犯罪): $\mathbf{f} \Leftarrow$ 恐れる (犯人, 死): $\left.\mathbf{f}.\right\}$.

$C k=\{$ 減少 (犯罪): $\mathbf{f}\}$ を仮定する.議論 $A_{1}=\left[r_{1}\right.$, $\left.r_{2}, r_{3}\right]$ と $A_{2}=\left[r_{5}, r_{6}\right]$ の間の打破関係について考える $A_{1}$ の結論には社会通念に反する結論「減少 (犯罪): $\mathbf{t} 」$ が含まれているため， $A_{2}$ は $A_{1}$ に対して間接的に社会的 な攻撃を行っている．一方， $A_{1}$ は $A_{2}$ を攻撃できない， よって， $A_{2}$ は $A_{1}$ を完全に打破している。

次に, $A_{3}=\left[r_{1}\right]$ と $A_{4}=\left[r_{4}\right]$ の打破関係について考え る. 2 つの議論は互いに攻撃を行っているが, $A_{4}$ は $A_{3}$ に対して直接的に社会的な攻撃を行っており， $A_{3}$ は $A_{4}$ に乥れ以上のレベルの攻撃を行うことができない.よっ て， $A_{4}$ は $A_{3}$ を完全に打破している。

$* 6$ 定義 16 の説明で述べた理由により，社会的に無効な攻撃は 打破関係として扱わない .

\section{5. 議論フレームワークの意味論}

この章では, 複数の知識ベースから作成できる議論全 体の集合の中で，打破関係から見てより優れている議論 を選び出すための意味論を与える.このような議論を，以 下では正当化された議論と呼ぶ .

一連の定義は [Dung 95, Prakken 97] の定義に基づい ているが, Dung らの定義が単一の知識ベースについて の意味論となっているのに対し，本論文で提案するのは 複数の知識ベースから作成できる議論についての意味論 である .

以下の定義では, 複数の知識ベース $K b_{1}, \ldots, K b_{n}$ の 存在を仮定する．乥して关れ光れの知識ベースから作成 できる議論を区別して扱うため，知識ベース $K b$ から作 成できるすべての議論の集合を $A r g s_{K b}$ と表記する．ま た $\operatorname{Args}_{\Gamma}=\operatorname{Args}_{K b_{1}} \cup \ldots \cup \operatorname{Args}_{K b_{n}}$ とする.ここで， $\operatorname{Args}_{\Gamma} \subseteq \operatorname{Args}_{K b_{1} \cup \ldots \cup K b_{n}}$ であることに注意されたい． すなわち, 各エージェントの知識ベースを合併すること は考えない．これは自然な設定であろう．

\section{$5 \cdot 1$ 意味論の定義}

ここでは不動点意味論を用いて，4 章で定義した議論 フレームワークにおける議論の正当化を定義する .

【定義 23】A 議論，Args を議論の集合とする．A を打破するすべての議論が Args の要素である議論によっ て完全に打破されるとき, A は Args に受理可能 (acceptable) であるという .

定義 23 の条件を満たす議論は, 乥の議論に対する異議 がすべて退けられたものとみなせる．乥こで，このよう な議論の集合を起点として正当化された議論を定義する．

【定義 24】 $S$ を $\mathrm{Args}_{\Gamma}$ の部分集合とする.議論フレー ムワークの特性関数 $F$ を以下のように定義する.

- $F_{A r g s_{\Gamma}}: \operatorname{Pow}\left(\operatorname{Args}_{\Gamma}\right) \rightarrow \operatorname{Pow}\left(\operatorname{Args}_{\Gamma}\right)$

- $F_{A r g s_{\Gamma}}(S)=\left\{A \in \operatorname{Args}_{\Gamma} \mid A\right.$ は $S$ に受理可能 $\}$ ここで, $\operatorname{Pow}(X)$ は集合 $X$ のべき集合を表す．

〈命題 3〉 $F_{A r g s_{\Gamma}}$ は集合の包含関係に関して単調であ る。

《証明》 $A r g s_{1}, A r g s_{2}$ を議論の集合とし，Args $\subseteq$ $A r g s_{2}$ を仮定する.また，議論 $A$ を $A r g s_{1}$ に受理可能 な議論であるとする .ここで $A$ を打破する議論 $B$ がある とすると, 受理可能の定義から $B$ を完全に打破する議論 $C \in \mathrm{Args}_{1}$ があるはずである . 仮定により C $\in \mathrm{Args}_{2}$ であるので, A $A \mathrm{Args}_{2}$ にも受理可能である .

$F_{A r g s_{\Gamma}}$ は単調であるから，最小不動点 $\operatorname{lfp}\left(F_{A r g s_{\Gamma}}\right)$ を 持つ [Tarski 55] . これを用いて，議論の正当化を次のよ うに定義する．正当化された議論は打破関係から見てよ り優れている議論であり，エージェント社会にとって受 け入れられる議論となる $(2 \cdot 2$ 節参照 $)$.

【定義 25】A を議論とする． 
- $A$ が $F_{A r g s_{\Gamma}}$ の最小不動点に含まれるとき，A は $\operatorname{Args}_{\Gamma}$ のもとで正当化(justified) される.

- $A$ が正当化されている議論から打破されているとき， $A$ は $\operatorname{Args}_{\Gamma}$ のもとで却下(overruled)される .

- $A$ が正当化も却下もされていないとき, $A$ は $\operatorname{Args}_{\Gamma}$ のもとで防御可能(defensible) である.

以下 $F_{\text {Args }_{\Gamma}}$ の最小不動点, すなわち正当化された議 論の集合をJustArgs J $_{\Gamma}$ で表す。

【定義 26】 $L: \mu$ を注釈付きリテラルとする $. L: \mu$ が 正当化された議論の結論であるとき, $L: \mu$ は $\operatorname{Args}_{\Gamma}$ の もとで正当化された結論であるという．

上で定義した $F_{A r g s_{\Gamma}}$ の不動点は, 特定の条件下で収 束し，具体的に計算することができる．弚の条件と計算 方法として，以下を定義する．

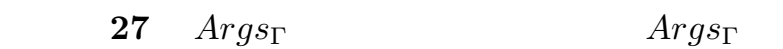
の有限個の議論から攻撃されているとき，Args ${ }_{\Gamma}$ は有限 的(finitary) である*7という [Dung 95] .

〈命題 4〉 以下のような $\operatorname{Args}_{\Gamma}$ の部分集合の列を定義 する .

- $F^{0}=\emptyset$

- $F^{i+1}=F_{A r g s_{\Gamma}}\left(F^{i}\right)$

(1) このとき,$\cup_{i=0}^{\infty}\left(F^{i}\right) \subseteq J u s t A r g s_{\Gamma}$.

(2) $\operatorname{Args}_{\Gamma}$ か洧限的ならば, $\cup_{i=0}^{\infty}\left(F^{i}\right)=J_{u s t A r g s}$.

《証明》（1）明らかに $\emptyset \subseteq J u s t A r g s_{\Gamma} . F_{\operatorname{Args}_{\Gamma}}$ の 単調性から $F_{\text {Args }_{\Gamma}}(\emptyset) \subseteq F_{\text {Args }_{\Gamma}}\left(\right.$ JustArgs $\left._{\Gamma}\right)$, すな わち $F^{1} \subseteq J u s t A r g s_{\Gamma}$. 同樣の手続きを繰り返すこ とにより，任意の $i$ につて $F^{i} \subseteq J u s t A r g s_{\Gamma}$. よっ $\tau \cup_{i=0}^{\infty}\left(F^{i}\right) \subseteq J u s t A r g s_{\Gamma}$.

(2) まず $F_{A r g s_{\Gamma}}$ の連続性，すなわち $\cup_{i=0}^{\infty}\left(F\left(F^{i}\right)\right)=$ $F\left(\cup_{i=0}^{\infty}\left(F^{i}\right)\right)$ を示す . 明らかに $F^{i} \subseteq \cup_{i=0}^{\infty}\left(F^{i}\right)$.

$F_{\text {Args }_{\Gamma}}$ の単調性から $F\left(F^{i}\right) \subseteq F\left(\cup_{i=0}^{\infty}\left(F^{i}\right)\right)$. よって $\cup_{i=0}^{\infty}\left(F\left(F^{i}\right)\right) \subseteq F\left(\cup_{i=0}^{\infty}\left(F^{i}\right)\right)$. 次に $\cup_{i=0}^{\infty}\left(F\left(F^{i}\right)\right)$ $\supseteq F\left(\cup_{i=0}^{\infty}\left(F^{i}\right)\right)$ を示す. $A \in F\left(\cup_{i=0}^{\infty}\left(F^{i}\right)\right)$ とする . $A$ に攻撃する議論は有限個であるから， $A \in F\left(F^{m}\right)$ となる数 $m$ が存在する.ゆえに $A \in \cup_{i=0}^{\infty}\left(F\left(F^{i}\right)\right)$.

以上から,$S=\cup_{i=0}^{\infty}\left(F^{i}\right)$ とすると $F(S)=$ $\cup_{i=0}^{\infty}\left(F\left(F^{i}\right)\right)=\cup_{i=1}^{\infty}\left(F^{i}\right)=S$ となる. ゆえに $S$ は $F$ の不動点である.よって $\cup_{i=0}^{\infty}\left(F^{i}\right)=S \supseteq$ $\operatorname{lfp}\left(F_{\text {Args }_{\Gamma}}\right)=$ JustArgs $_{\Gamma}$.

以下の理論展開では, $\operatorname{Args}_{\Gamma}$ は有限的であると仮定 する .

以上の定義によって与えられる議論フレームワークと光 の意味論は, 光れ光れの命題に対して存在する複数の認識 から光の共通認識として認められる部分を結論とした議論 を基本的に正当とするという特徵を持つ.たとえば $L: T$ のみを結論に持つ議論と $L: \mathbf{t}$ のみを結論に持つ議論と が存在した場合, 前者の結論は $\{L: \top, L: \mathbf{t}, L: \mathbf{f}, L: \perp\}$

*7 知識ベースが有限個の規則から構成されている，という意味 での「有限」とは異なる .
を，後者の結論は $\{L: \mathbf{t}, L: \perp\}$ を乥れぞれ成立しうる論 理的帰結の範囲として主張している．このとき後者の議 論が前者の議論を打破することにより，2つの共通部分 である $\{L: \mathbf{t}, L: \perp\}$ を主張する結論が正当化された結論 として選ばれることになる。

\section{$5 \cdot 2$ 正当化議論の判別例}

この節では, 複数の知識ベースから作成できる議論の 中で正当となる議論がどれであるかを判定する例を示す．

〔例 6〕 $C k=\{$ 減少 (犯罪) : f $\}$ を仮定した上で, 例 3 で示した $K b_{3}$ から作成できる議論 $A_{1} \sim A_{5}$, 乥して以 下の知識ベース $K b_{8}, K b_{9}$ の弚れ光れから作成できる議 論について考える.なお， $K b_{8}$ は死刑制度に賛成する立 場の知識， $K b_{9}$ は死刑制度に反対する立場の知識， $K b_{3}$ は死刑制度に対して賛成・反対の両方の考えを持つ立場 の知識を表す .

$K b_{8}=\{$

$r_{6}$ : 望む (遺族, 死刑): t.,

$r_{7}:$ 賛成 (死刑): $\mathbf{t} \Leftarrow$ 望む (遺族, 死刑): $\mathbf{t} .$,

$r_{8}:$ 償う (死, 罪): $\mathbf{t}$.,

$r_{9}:$ 賛成 (死刑): $\mathbf{t} \Leftarrow$ 償 j (死, 罪): $\left.\mathbf{t}.\right\}$.

$K b_{9}=\{$

$r_{10}$ : 反省 (死人): $\mathbf{f}$.,

$r_{11}$ : 償 j (死, 罪) : $\mathbf{f} \Leftarrow$ 反省 (死人): $\mathbf{f} .$,

$r_{12}$ : 賛成 (死刑): $\mathbf{f} \Leftarrow$ 償う (死, 罪): $\mathbf{f}$.,

$r_{13}:$ 減少 (犯罪): f.,

$r_{14}$ : 抑止 (死刑, 犯罪): $\mathbf{f} \Leftarrow$ 減少 (犯罪): $\left.\mathbf{f}.\right\}$.

$K b_{8}$ から，次の 4 つの議論が作成できる (図 3 の左側 を参照）. $A_{6}=\left[r_{6}, r_{7}\right], A_{7}=\left[r_{6}\right], A_{8}=\left[r_{8}, r_{9}\right], A_{9}=$ $\left[r_{8}\right]$. また $K b_{9}$ から，次の 5 つの議論が作成できる（图 3 の右下を参照) . $A_{10}=\left[r_{10}, r_{11}, r_{12}\right], A_{11}=\left[r_{10}, r_{11}\right]$, $A_{12}=\left[r_{10}\right], A_{13}=\left[r_{13}, r_{14}\right], A_{14}=\left[r_{13}\right]$. 以上の $A_{1} \sim$ $A_{14}$ の中から，正当化できる議論を計算する .

空集合に受理可能，すなわちどの議論からも打破さ れていない議論の集合 $F^{1}$ は $F^{1}=\left\{A_{2}, A_{4}, A_{11}, A_{12}\right.$, $\left.A_{13}, A_{14}\right\}$ となる.なぜならば, $A_{4}, A_{12}$ はどの議論から も攻撃されていない． $A_{13}, A_{14}$ は $A_{1}, A_{3}, A_{5}$ から攻撃 されているが, 弚れら 3 つの議論に対して直接的に社会 的な攻撃を行っているため，打破はされていない，同樣 に， $A_{2}$ と $A_{11}$ は自分を攻撃する議論に対して根拠の多 さに基づく攻撃を行っているため勝っており，結果とし て打破されていない，次に，この $F^{1}$ に受理可能な議論 を探すと $A_{10}$ が該当する.$A_{10}$ は $A_{1}, A_{6}, A_{8}$ から攻撃 されているが， $A_{1}, A_{8}$ からは打破されていない（ $A_{1}$ に は間接的に社会的な攻撃によって勝っており， $A_{8}$ には根 拠の多さに基づく攻撃によって勝っている).一方， $A_{6}$ は $A_{10}$ を打破しているが, 同時に $A_{2} \in F^{1}$ から根拠の多 さに基づく攻撃によって完全に打破されている．よって $A_{10} \in F_{A r g s_{\Gamma}}\left(F^{1}\right)$.これ以外で $F_{A r g s_{\Gamma}}\left(F^{1}\right)$ に含まれる 議論は $F^{1}$ の要素のみである .よって $F^{2}=F^{1} \cup\left\{A_{10}\right\}$. 


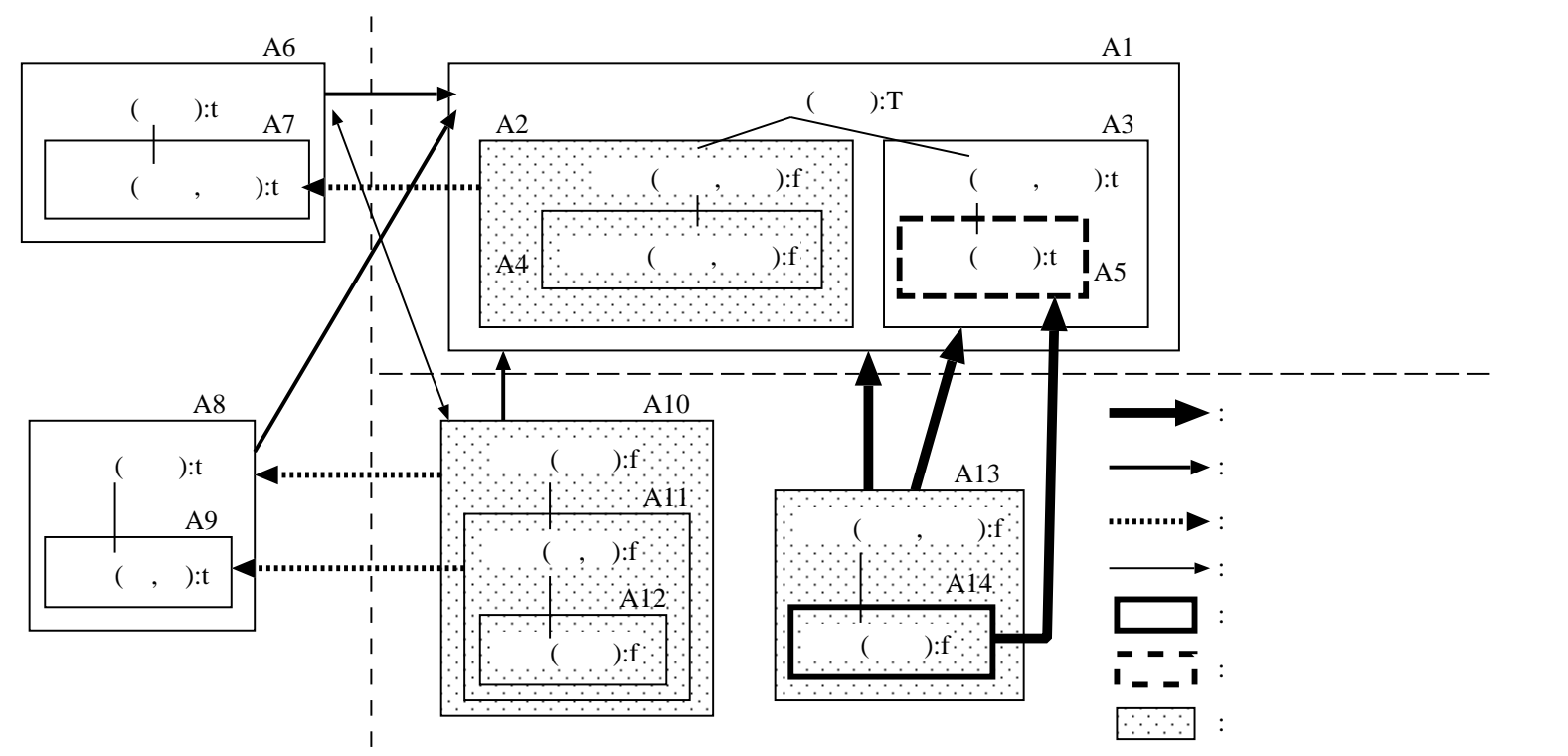

図 3 例 3 の $K b_{3}$ から作られる議論 $\left(A_{1} \sim A_{5}\right)$, 例 6 の $K b_{8}$ から作られる議論 $\left(A_{6} \sim A_{9}\right), K b_{9}$ から作られ る議論 $\left(A_{10} \sim A_{14}\right)$ と光れ光れの攻撃関係 (議論間で, 通常の攻撃とレベル 2 以上の攻撃が同時に発生 している部分に関しては通常の攻撃の表記を省略)

$F^{2}$ に受理可能な議論は $F^{2}$ の要素以外には存在せず , $F^{2}$ は $F_{\text {Args }_{\Gamma}}$ の最小不動点となる . これが $K b_{3}, K b_{8}, K b_{9}$ から作成できる議論の中で正当化される議論の集合とな る.

$F_{2}$ の内容を全体的に見ると，兴の主旨は「遺族は死刑 を望まない . また , 死刑は犯罪の抑止にならない , 光して 死で罪は償えないので死刑制度に反対」となる.これは， $K b_{3}, K b_{8}, K b_{9}$ を乥れ光れ知識ベースに持つ 3 体のエー ジェントでエージェント社会を構成したとき，社会全体に とって受け入れることのできる議論，すなわち社会全体 の主義を表している.以上のことは，正当化される議論の 選択がェージェント社会の規範の決定や, e-government へと応用できることを示唆している

\section{$5 \cdot 3$ 意味論の性質}

我々の議論フレームワークにおいて, [Prakken 97] の フレームワークと同樣に以下の性質が成り立つ.

〈命題 5〉 正当化された議論の集合は無衝突である.

《証明》任意の $i$ につて命題 4 の $F^{i}$ が無衝突であ ることを $F$ の反復回数 $i$ にいての数学的帰納法で示す

まず， $F^{1}$ が無衝突であることを示す $. A, A^{\prime} \in F^{1}$ と し， $A$ が $A^{\prime}$ を攻撃すると仮定する .このとき， $A, A^{\prime}$ に ついて以下のいずれかが成り立つ.

・ $A$ は $A^{\prime}$ を打破するが， $A^{\prime}$ は $A$ を打破できない

・ $A$ が $A^{\prime}$ を打破し，同時に $A^{\prime}$ が $A$ を打破する

・ $A$ は $A^{\prime}$ を打破できないが， $A^{\prime}$ が $A$ を打破する

いずれの場合も， $F^{1}$ が空集合に受理可能 (どの議論から も打破されていない議論の集合) であるという仮定に反 する.よって $F^{1}$ は無衝突である .

次に $F^{i}$ が無衝突と仮定したとき, $F^{i+1}$ が無衝突であ
ることを示す $. A, A^{\prime} \in F^{i+1}$ とし,$A$ が $A^{\prime}$ を攻撃する と仮定する .このとき $A, A^{\prime}$ について以下のいずれかが 成り立つ。

・ $A$ は $A^{\prime}$ を打破するが， $A^{\prime}$ は $A$ を打破しない .この とき $A$ を完全に打破する $B \in F^{i}$ が存在する .

- $A$ が $A^{\prime}$ を打破し，同時に $A^{\prime}$ が $A$ を打破する .こ のとき $A$ を完全に打破する $B \in F^{i}$ が存在する . ま た， $A^{\prime}$ を完全に打破する $B^{\prime} \in F^{i}$ が存在する.

・ $A$ は $A^{\prime}$ を打破できないが， $A^{\prime}$ が $A$ を打破する .こ のとき $A^{\prime}$ を完全に打破する $B^{\prime} \in F^{i}$ が存在する . いずれの場合も $A, A^{\prime}$ が $F^{i}$ に受理可能であることから， $B, B^{\prime}$ を完全に打破する $C \in F^{i}$ が存在する . しかしこ れは帰納法の仮定に反する.よって $F^{i+1}$ は無衝突であ る。

〈命題 6〉 $A$ を議論とする.$A$ が正当化されていると き, $A$ の部分議論はすべて正当化されている .

《証明》 $A \in J u s t A r g s_{\Gamma}$ とする. $A^{\prime}$ を $A$ の部分議論 とする．以下のような場合分けを行い，乥れ光れの場合 でA $A^{\prime} \in J u s t A r g s_{\Gamma}$ となることを示す．

（1） $A^{\prime}$ は他のどの議論からも打破されていない .

(2) $B$ を， $A^{\prime}$ を打破する任意の議論とする .

(2a) $A^{\prime}$ は $B$ から打破されているが， $B$ は $A$ を 打破していない

(2b) $A^{\prime}$ は $B$ から打破されていて ,さらに $B$ は $A$ を打破している。

(1) の場合 $A^{\prime} \in F_{\text {Args }_{\Gamma}}(\emptyset)$ なので $A^{\prime} \in J u s t A r g s_{\Gamma}$.

(2) の場合

(2a): この場合， $B$ は $A, A^{\prime}$ を攻撃しているが $A$ を打 破していない，つまり， $A$ は $B$ を完全に打破し ている。

(2b): $A$ は既に正当化されているので， $B$ を完全に打 
破するような議論 $C \in J u s t A r g s_{\Gamma}$ が存在する. 従っていずれの場合も, $B$ はある JustArgs $s_{\Gamma}$ の要素 によって打破される. よって $A^{\prime} \in$ Just Args $_{\Gamma}$.

\section{6. 対話的証明論}

ここでは，異なる知識ベースを持つ複数のエージェン 卜か対話的に議論を提出し合うことによって，特定の議論 が正当化できるか否かを決定するための証明論を与える .

一連の定義は [Prakken 97] の定義に基づいているが， Prakken らの定義は単一の知識ベースから作成できる議 論について二者が対話的証明を行うものであるのに対し， 本論文で提案するのは複数の知識ベース (多者) から作成 できる議論を対話的に証明する証明論である．以下では 5 章と同樣に, 複数の知識ベース $K b_{1}, \ldots, K b_{n}$ と $A r g s_{\Gamma}$ の存在を仮定する .

\section{$6 \cdot 1$ 対話的証明論の定義}

まず対話を定義する．これは，直前の議論を打破また は完全に打破するように議論を並べた列である .

【定義 28】対話(dialogue) は,以下の条件を満たす有 限で空でない議論の列 $\left[A r g^{1}, \ldots, A r g^{n}\right]$ である .ただし 任意の $i$ について $\operatorname{Arg}^{i} \in \operatorname{Args}_{\Gamma}$. また , $n$ を対話の長さ という.

(1) $i(i \geq 3)$ が奇数のとき $A{ }^{i} g^{i}$ は $A r g^{i-1}$ を完全に 打破する議論のうちで集合の包含関係に関して極小 となる議論である .

(2) $i(i \geq 2)$ が偶数のとき, $A_{r g}^{i}$ は $A r g^{i-1}$ を打破す る議論である .

(3) $i, j$ が奇数で $i \neq j$ のとき, $A r g^{i} \neq A r g^{j}$.

定義 28 によって構成される対話は次のような性質を 持つ . 対話の終端の議論 $A r g^{n}$ を打破する議論が $A r g s_{\Gamma}$ に存在しないとき, Arg $^{n} \in J u s t A r g s_{\Gamma}$ である .さらに , もし対話の長さ $n$ が奇数であり，かつ任意の偶数の $i$ につ いて $A r g^{i-1}$ を打破する議論 $A r g^{i}$ が光れ光れひとつしか 存在しない場合は, $A r g^{n-2}, A r g^{n-4}, \ldots, A r g^{3}, A r g^{1}$ が JustArgs $s_{\Gamma}$ に受理可能となり，光れ光れ正当化される. このことから，対話の偶数番目の議論は $A r g^{1}$ の正当化 を助けている議論であると捉えることができる(対話が 奇数番目の議論で終端となれば $A r g^{1}$ が正当化される）. しかし, 対話の奇数番目の議論において対話がループに なってしまうと，この目的から外れるだけでなく対話が 無限に続く恐れがある．弚のような状況を防ぐため，定 義 28 では条件 (3) か導入されている . また , 条件 (1) で 「集合の包含関係に関して極小」としているのは , $A r g^{1}$ の正当化を助ける議論として, 必要最小限の規則だけか ら構成された議論のみを用いるためである .

ところで一般には，各議論を打破する議論は複数存在 する . 兴のため, 対話単体で $A r g s_{\Gamma}$ 内のすべての打破関 係を表現することはできず, 受理可能の定義をとのまま

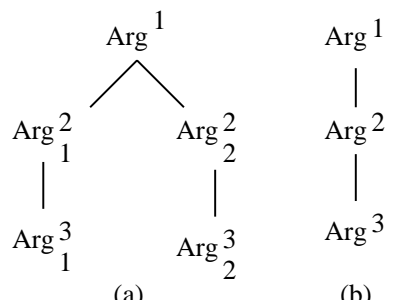

図 4 (a) 対話木の例 (b) 例 7 における正当化された対話木

上記のように適用することはできない . 光こで以下のよ うな対話木を導入する．

【定義 29】対話木(dialogue tree) は, 以下の条件を 満たす有限な議論の木である .

（1）木の根から，木の任意の葉へ至るすべてのパスが 対話である 。

（2）iが奇数のとき，ノード $A r g^{i}$ の子は $A r g^{i}$ を打破 するすべての議論である .

また対話木の高さを，対話木に含まれる対話の中で最も 長い対話の長さとする .

図 4(a) に,2つの対話 $\left[A r g^{1}, A r g_{1}^{2}, A r g_{1}^{3}\right],\left[A r g^{1}\right.$, $\left.A r g_{2}^{2}, A r g_{2}^{3}\right]$ から構成される高さ 3 の対話木の例を示す . 以下ではこの例のように , 木の根からの距離が同一とな るノードが対話木に複数存在するときには，乥れ光れの ノードにある議論を $A r g_{1}^{i}, A r g_{2}^{i}, \ldots$ のように添字をつけ て表記し区別する .

定義 29 に従って対話木を構成すると，木の根にある議 論が正当化されるかどうかを受理可能の定義に従って判 定することができる . 対話的証明論における正当化を次 のように定める .

【定義 30】 $A$ を議論とする . 木の根の議論が $A$ であ り，かつ木に含まれるすべての対話の長さが奇数となる 対話木が存在するとき, 議論 $A$ は証明論的に正当化され る (provably justified) という.また，炎のような対話木 を正当化された対話木という.

【定義 31】 $L: \mu$ を注釈付きリテラルとする $. L: \mu$ は 証明論的に正当化された議論の結論であるとき，証明論 的に正当化された結論であるという．

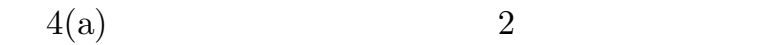
どちらも奇数となっているので正当化された対話木であ る .よって $\mathrm{Arg}^{1}$ は証明論的に正当化される .

\section{$6 \cdot 2$ 対話的証明の例}

〔例 7〕 例 6 で示した議論 $A_{1} \sim A_{14}$ について再度考 える. $C k=\{$ 減少 (犯罪): $\mathbf{f}\}$ を仮定し, 意味論上で正 当化された $A_{10}$ か証明論的に正当化されるか否かを対話 木を構成して判定する . 各議論間の攻撃関係は例 6 と同 じである (図 3 参照) .

まず木の根の議論 $\mathrm{Arg}^{1}$ を $A_{10}$ とする .この議論を打 破する議論は $A_{6}$ のみである $\left(A_{1}, A_{8}, A_{9}\right.$ は $A_{10}$ を攻 
撃しているが, 逆に $A_{10}$ からよりレベルの高い攻撃を受 けており， $A_{10}$ を打破できない）。乥こで $\mathrm{Arg}^{2}=A_{6}$ と おく.この議論を完全に打破する議論として $A_{2}$ がある 光こで $\mathrm{Arg}^{3}=A_{2}$ とおく.この $A_{2}$ を打破できる議論は 存在せず，結局 $\mathrm{Arg}^{3}$ は対話の終端の議論となる .この 対話木は正当化された対話木であるので, 対話木の根の 議論 $A_{10}$ は証明論的に正当化される。

この例て構成した，正当化された対話木の状態を図 4(b) に示す.

\section{$6 \cdot 3$ 対話的証明論の性質}

ここでは, 5 章の意味論によって正当化された議論と， 証明論的に正当化された議論が一致することを示す．

[ 定理 1]（健全性）証明論的に正当化された議論は， 正当化される.

《証明》 証明論的に正当化された任意の議論を $A r g \in$ $\operatorname{Args}_{\Gamma}$ とする .このとき，根の議論が $\mathrm{Arg}$ で高さが奇 数である正当化された対話木が存在する. 以下，すべて の奇数の $i$ につて, Arg を根に持ち高さが $i$ の正当化 された対話木が存在するとき $\mathrm{Arg} \in \mathrm{JustArgs} \mathrm{s}_{\Gamma}$ である ことを, $i$ についての数学的帰納法を用いて示す .

まず，高さ 1 の対話木を考える .このとき対話木は根の 議論 $A r g$ のみから構成されている. Arg はどの議論から も打破されていないので，明らかに Arg $\in$ JustArgs $s_{\Gamma}$. 次に, 高さが $i$ の正当化された対話木において关の根 の議論が正当化されていると仮定したとき，高さが $i+2$ の正当化された対話木において根の議論 $\mathrm{Arg}$ が $\mathrm{Arg} \in$ JustArgs $_{\Gamma}$ となることを示す . 高さが $i+2$ の正当化さ れた対話木を $T_{i+2}$ とする. $T_{i+2}$ の根の議論を $\mathrm{Arg}^{1}$ と し，弚の子を $\operatorname{Arg}_{j}^{2}(1 \leq j \leq l)$ とする. $A r g_{j}^{2}$ の乥れ光れ の子を，議論 $A r g_{j}^{3}$ を根に持ち高さが $i$ の正当化された対 話木 $T_{i j}$ とする. 帰納法の仮定から $A r g_{j}^{3} \in J u s t A r g s_{\Gamma}$. また対話木の構成から， $\mathrm{Arg}^{1}$ は $A r g_{j}^{3}$ が属す集合に受理 可能である.よって Arg $^{1} \in J_{u s t A r g} s_{\Gamma}$.

[ 定理 2]（完全性） $\operatorname{Args}_{\Gamma}$ が有限的ならば，正当化 された議論は証明論的に正当化される .

《証明》任意の正当化された議論 $\mathrm{Arg} \in J u s t \operatorname{Args}_{\Gamma}$ を考える．このとき命題 4 により，以下の条件を満たす $\operatorname{Args}_{\Gamma}$ の無衝突な部分集合の有限な列 $F^{0}, \ldots, F^{n}$ が存在 する .

- $F^{0}=\emptyset . F^{i+1}=F_{A r g s_{\Gamma}}\left(F^{i}\right)$.

- $n$ は $F^{n} \subseteq J u s t A r g s_{\Gamma}$ かつ Arg $\in F^{n}$ となるよう な最小の数である.

このときすへてての $i(0 \leq i \leq n)$ に対し， $A r g \in F^{i}$ で あれば $A r g$ を根にもち高さが $2 i-1$ 以下の正当化され た対話木 $T_{i}$ が存在することを, $F$ の反復回数 $i$ につて の数学的帰納法で証明する.

$i=0$ の場合， $A r g \in F^{0}$ となる $A r g$ は存在しない .

$i=1$ の場合,$A r g \in F^{1}=F_{\operatorname{Args}_{\Gamma}}(\emptyset)$ であり, Arg を 打破できる議論は存在しない.よって $\operatorname{Arg}$ のみで構成
される議論の木は，高さ 1 の正当化された対話木 $T_{1}$ で ある

次に, $i=k$ の場合において正当化された対話木 $T_{k}$ が 存在すると仮定したとき， $i=k+1$ の場合においても 正当化された対話木 $T_{k+1}$ が存在することを示す . 以下 $A r g \in F^{k+1}$ となるすべての $A r g$ を $A r g \in F^{k}$ となる 場合と $A r g \notin F^{k}$ となる場合に分けて考える .

はじめに $A r g \notin F^{k}$ となる場合について考える.$A r g$ $\in F^{k+1}$ であれば，Arg は $F^{k}$ に受理可能である .よっ て,$A r g$ を打破するすべての議論 $A r g_{j}^{2}(1 \leq j \leq l)$ に対 して,$A r g_{j}^{2}$ を完全に打破する議論のうち包含関係に関 して極小であるような議論 $A r g_{j}^{3} \in F^{k}$ が存在する . また 帰納法の仮定により， $A r g_{j}^{3}$ を根に持ち，正当化された対 話木 $T_{k}$ が存在する .このとき $A r g$ を根に持ち，Argの 子が $\mathrm{Arg}_{j}^{2}, \mathrm{Arg}_{j}^{2}$ の兰れ光れの子が $T_{k}$ であるような高 さ $k+1$ の対話木は，正当化された対話木である .

次に, $A r g \in F^{k}$ となる場合について考える.この場 合は帰納法の仮定により，Arg を根とした高さ $k$ 以下の 正当化された対話木が存在する.

証明論的に正当化された議論は以下の性質を持つ．

〈命題 7〉議論か証明論的に正当化されていれば，光 の部分議論も証明論的に正当化されている.

《証明》命題 6 と定理 1,2 より直ちに導かれる.

7. 結 論

本論文では，古典論理上では矛盾となる知識を扱うこ とができる準無矛盾論理を知識表現言語として採用し， その上で議論フレームワークを構築した . また，議論間 の衝突関係を真理値の順序構造に基づいて定義し，光の 衝突を解決するための判断基準としてェージェント社会 の社会通念による基準と議論の根拠の多さに基づく形式 的な基準の 2 種類を導入した .さらに，正当な議論を判 定するための意味論と対話的証明論を与え，弚の健全性 と完全性を示した .これらは複数の知識ベースから作成 された議論について定義されており，マルチェージェン トシステムに適用することによってェージェント間の意 思決定問題へと応用することができる．

今後の課題としては, まず実際にエージェント間の問題 解決に有効であることを示すため, 提案した議論フレー ムワークをマルチェージェントシステムへ実装する必要 がある．また，本論文では社会通念を注釈付きリテラル の集合としたが，日常的に用いられている社会通念には 規則の形で表現するのが適切なものも存在する . 乥こで， エージェントの社会通念を規則形式に拡張することを検 討している . 次にフレームワークの拡張の可能性として , [Umeda 00, 梅田 02] て提案されている協調機構の導入が ある .これは相手の議論の根拠を補強する知識を提供す ることによって協調を申し出るという仕組みである．真 理值 $丁, \perp て ゙$ 表現された根拠への補強を定めることによ 
り，この機構を本論文の議論フレームワークへ導入する ことが可能となる .さらに他のシステムへの応用の可能 性として , ネットワーク上を移動し議論の形で知識を収 集するモバイルェージェント [Kawakami 02] への応用が ある .このシステムに本論文の議論フレームワークを適 用することにより，矛盾問題を考慮することなく知識獲 得が行える，エージェント社会の主義に合った知識を優 先して集めることが可能，といった効果が期待できる．

\section{$\diamond$ 参 考 文 献 $\diamond$}

[Belnap 77] Belnap, N.: A Useful Four-valued Logic, Modern uses of multiple-valued logic, pp. 8-37 (1977)

[Blair 89] Blair, H. and Subrahmanian, V.: Paraconsistent Logic Programming, Theoretical Computer Science, Vol. 68, pp. 135-154 (1989)

[Carlos 00] Carlos, C., Ana, I., Maguitman, G., and Loui, R.: Logical Models of Argument, ACM Computing Surveys, Vol. 32, No. 4, pp. 337-383 (2000)

[Dung 95] Dung, P. M.: On the Acceptability of Arguments and its Fundamental Role in Nonmonotonic Reasoning, Logic Programming and N-person Games, Artificial Intelligence, Vol. 77, pp. 321-357 (1995)

[Ferber 99] Ferber, J.: Multi-Agent Systems (1999)

[Kawakami 02] Kawakami, W., Umeda, Y., and Sawamura, H.: Agents that Grow by Means of Arguability and Mobility, Proc. of The Sixth Australia-Japan Joint Workshop on Intelligent and Evolutionary Systems, pp. 33-40 (2002)

[Kifer 92] Kifer, M. and Subrahmanian, V. S.: Theory of Generalized Annotated Logic Programming and its Applications, Journal of Logic Programming, Vol. 12, No. 3\&4 pp. 335-367 (1992)

[Loui 87] Loui, R.: Defeat Among Arguments: A System of Defeasible Inference, Computational Intelligence, Vol. 3 , No. 2, pp. 100-106 (1987)

[Prakken 97] Prakken, H. and Sartor, G.: Argument-based Extended Logic Programming with Defeasible Priorities, Journal of Applied Non-Classical Logics, Vol. 7, pp. 25-75 (1997)

[Sawamura 00] Sawamura, H., Yamashita, M., Inagaki, M., and Umeda, Y.: Agents Meet Dialectics, Proc. of International ICSC Symposium on Multi-Agents and Mobile Agents in Virtual Organizations and E-Commerce (MAMA2000), pp. 354-360 (2000)

[Schroeder 99] Schroeder, M.: An Efficient Argumentation Framework for Negotiating Autonomous Agents, Proc. of the workshop on Modelling Autonomous Agents in a MultiAgent World, Vol. 1647, pp. 140-149 (1999)

[Sycara 90] Sycara, K. P.: Persuasive Argumentation in Negotiation, Theory and Decision, Vol. 28, pp. 203-242 (1990)

[Tarski 55] Tarski, A.: A Lattice-Theoretical Fixpoint Theorem and its Application, Pacific Journal of Mathmatics, Vol. 5, pp. 285-309 (1955)

[Umeda 00] Umeda, Y., Yamashita, M., Inagaki, M., and Sawamura, H.: Argumentation as a Social Computing Paradigm, Design and Applications of Intelligent Agents, Lecture Notes in Artificial Intelligence, Vol. 1881, pp. 46$60(2000)$

[梅田 02] 梅田 勇一, 沢村 一 : 議論を計算とコミュニケーション の基本メカニズムとするエージェントシステム, 情報処理学会 論文誌, Vol. 43, No. 5, pp. 1518-1527 (2002)

〔担当委員：北村泰彦〕

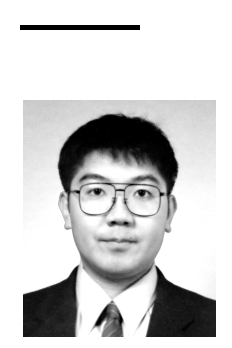

\section{紹}

梅田 勇一(学生会員)

1999 年新潟大学工学部情報工学科卒業 . 2001 年新潟大 学大学院自然科学研究科博士前期課程修了. 現在, 同研究 科博士後期課程在学中 . エージェントコミュニケーション に興味をもつ。

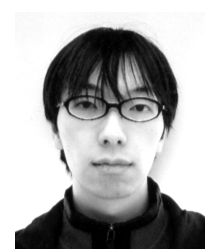

高橋 武久(学生会員)

2001 年新潟工科大学工学部情報電子工学科卒業. 現在, 新潟大学大学院自然科学研究科博士前期課程在学中. エ一 ジェントの知識表現に興味をもつ。

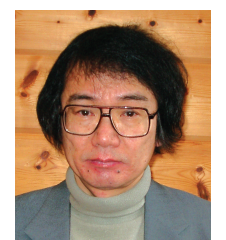

\section{沢村 - (正会員)}

1978 年北海道大学大学院工学研究科情報工学専攻単位修得 退学. 1980 年-1996 年 (株) 富士通国際情報社会科学研 究所,(株) 富士通研究所情報 社会科学研究所で, 主任研究 員,室長, 主管研究員などを歴任. 1989 年-1990 年 オー ストラリア国立大学 Visiting Fellow . 2002 年-2003 年 ニュージーランドヴィクトリア大学 Visiting Fellow 1996 年-現在 新潟大学工学部情報工学科助教授, 博士 (工 学)、計算論理学、ソフトウェア基礎論, 人工知能分野に 興味をもつ. 情報処理学会, ソフトウェア科学会, 日本科学哲学会各会員. 